\title{
Rancang Bangun pH Meter Otomatis Menggunakan ATMega16 Dalam Upaya Peningkatan Akurasi Pembacaan pH Larutan Senyawa Kimia
}

\author{
Risal Arief ${ }^{1}$, Hardianto $^{2}$, Arief Muliawan ${ }^{3}$ \\ Program Studi Teknik Elektro \\ Sekolah Tinggi Teknologi Bontang (STITEK) \\ Bontang, Indonesia \\ risalarief26@gmail.com ${ }^{1}, \underline{\text { hard_yan@yahoo.com }}$, ariefstitek@gmail.com
}

\begin{abstract}
Abstraksi-Penggunaan indikator pH konvensional untuk pengujian larutan senyawa kimia tidak dapat menunjukkan angka pH dengan signifikan karena merupakan hasil pembacaan dengan cara pendekatan pada warna trayek $\mathrm{pH}$ serta dampak lainnya berupa masalah keselamatan dari penguji pH. Penelitian dilakukan dengan merancang bagun sebuah alat yang dapat memberikan nilai akurasi pembacaan nilai $\mathrm{pH}$ dapat meninggkat dari pada menggunakan indikator konvensional. Alat ini akan bekerja secara otomatis menggerakan probe sensor $\mathrm{pH}$ naik dan turun sehingga masalah keselamatan di atas dapat diminimalkan dampaknya dan dapat mempermudah kerja penguji pH. Rancang bangun alat berupa pH Meter yang menggunakan mikrokontroler ATMega16. Dalam penelitian dilakukan pengamatan beberapa parameter uji serta dilakukan analisa terhadap beberapa sampel larutan kimia yaitu $\mathrm{HNO}_{3}$ (Asam Nitrat), $\mathrm{CH}_{3} \mathrm{COOH}$ (Asam Cuka), Aquadest, Antiseptik, dan NaOH (Natrium Hidroksida). Dari pengujian alat didapatkan hasil akurasi pembacaan nilai $\mathrm{pH}$ dengan perhitungan standar deviasi dibawah 0.1 , sehingga dapat disimpulkan bahwa pH Meter yang dirancang bangun oleh peneliti bekerja sesuai fungsinya
\end{abstract}

Katakunci-Asam Basa; pH Meter; ATMega16

\section{PENDAHULUAN}

Dewasa kini banyak sekali senyawa kimia berupa larutan asam basa dan garam (netral) yang digunakan sebagai media pembelajaran di perguruan tinggi dan sekolah-sekolah yang memiliki mata pelajaran kimia khususnya di daerah kota Bontang [1]. Sebelum larutan senyawa kimia itu digunakan, terlebih dahulu harus mengetahui karakteristik dari larutan tersebut. Untuk itu mengetahui karakteristik larutan salah satunya dilakukan pengukuran $\mathrm{pH}$ untuk mengetahui apakah larutan itu bersifat asam, basa, dan netral. Biasanya cara yang digunakan untuk menentukan sifat dan $\mathrm{pH}$ larutan adalah dengan menggunakan indikator. Indikator tersebut antara lain kertas lakmus, larutan fenolftalein, brom timol biru, metil merah, metil orange, serta Indikator Universal [2]. Pengukuran $\mathrm{pH}$ larutan yang lazim biasanya dilakukan secara manual menggunakan kertas lakmus dan indikator universal. Indikator konvensional ini memiliki prinsip kerja perubahan warna pada kertas indikator tergantung sifat dari larutan senyawa kimia yang diuji apakah larutan tersebut bersifat asam atau larutan tersebut bersifat basa [3].

Indikator tersebut diatas tidak dapat memberikan hasil akurat dan tidak dapat menampilkannya di display, kerena penguji $\mathrm{pH}$ harus membandingkan warna indikator secara manual yang terdapat pada kemasan indikator universal [4]. Pada kemasan indikator universal terdapat range $\mathrm{pH}$ berupa nilai satuan dan warna gradasi pembanding yang tidak jauh berbeda antar setiap warna [5], sehingga penguji $\mathrm{pH}$ akan kesuilitan membandingkan nilai $\mathrm{pH}$ dari larutan yang diuji dan nilai $\mathrm{pH}$ hanya berupa 1 (satu) digit angka atau dapat dikatakan tidak dapat menunjukkan angka $\mathrm{pH}$ suatu larutan dengan signifikan, sehingga nilai $\mathrm{pH}$-nya tidak akan akurat dan dapat mempengaruhi pengujiaan lanjutan dari larutan senyawa kimia tersebut. Penggunaan indikator $\mathrm{pH}$ konvensional memiliki dampak lain berupa masalah keselamatan dari penguji $\mathrm{pH}$ dikarenakan penguji harus berinteraksi langsung dengan larutan kimia yang bersifat asam dan basa, beberapa larutan asam dapat menyebabkan luka bakar apabila terkena tangan dan beberapa larutan basa dapat menyebabkan iritasi pada kulit dikarenakan penguji harus mencelupkan secara langsung indikator universal pada larutan kimia dalam wadah [6].

Dari permasalahan diatas diperlukan sebuah alat yang bekerja secara otomatis sehingga masalah keselamatan dapat diatasi. Alat ini diharapkan dapat menampilkannya nilai $\mathrm{pH}$ yang signifikan pada display saat pengukuran $\mathrm{pH}$ sebuah larutan sehingga akurasi pembacaan nilai $\mathrm{pH}$ dapat 
meninggkat daripada menggunakan indikator konvensional [4]. Alat ini bekerja dengan menggunakan pengontrol elektronik berupa Mikrokontroler. Proses kontrol menggunakan Mikrokontroler memiliki rangkaian yang lebih sederhana dari pengontrol lainnya [7]. Mikrokontroler ini mudah didapat dipasaran dan juga dari segi kapasitas karakteristik komponen mendukung untuk aplikasi kerja sistem yang dirancang [8]. Peneliti akan menggunakan ATMega16 yang merupakan salah satu jenis dari Mikrokontroler, ATMega16 memiliki potensi kemampuan komputasi yang relatif tinggi, harga murah, dan kemudahan pemrograman [9].

Berdasarkan latar belakang diatas peneliti akan merancang bangun sebuah alat $\mathrm{pH}$ Meter otomatis yang diharapakan dapat menyelesaikan permasalahan diatas dan diharapkan juga dapat meningkatkan akurasi pembacaan nilai $\mathrm{pH}$ larutan senyawa kimia dari pada menggunakan indikator konvensional.

\section{METODE}

Dalam penelitian rancang bangun $\mathrm{pH}$ meter ini menggunakan Liquid pH Probe Sensor Tester Composite Electrode E-201 BNC Interface, motor yang dapat menggerakan naik dan turun sistem dari sensor $\mathrm{pH}$ ditempatkan, dan pada alat juga diberi sensor halangan yang dapat mendeteksi objek ketika larutan yang terdapat dalam wadah diletakkan dibawah sensor $\mathrm{pH}$ berada. Dalam implementasinya $\mathrm{pH}$ Meter Otomatis Menggunakan mikrokontroler ATMega16. Mikrokontroler ATMega16 memiliki keunggulan dibandingkan dengan yang lainnya, keunggulannya yaitu pada kecepatan eksekusi program yang lebih cepat karena sebagian besar instruksi dieksekusi dalam 1 siklus clock [10].

Perancangan dan pembuatan perangkat lunak terdiri dari: Perancangan flow chart dan pembuatan program dengan menggunakan CodeVision AVR. Untuk flow chart seperti yang ditunjukkan Gambar 1 dibawah ini.

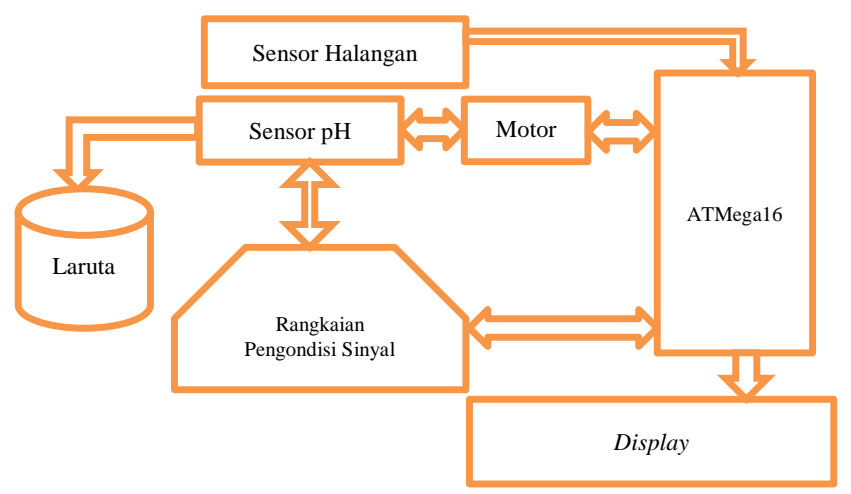

Gambar 1. Flow Chart Sistem Pengukur $\mathrm{pH}$

\section{A. Perancangan Hardware $\mathrm{pH}$ Meter}

i). Perancangan $\mathrm{pH}$ Meter Menggunakan Sensor Probe $\mathrm{pH}$

Prinsip kerja sistem yang akan dirancang ini adalah sensor yang terdiri dari sensor pH (Glass Electrode) seperti yang ditunjukkan pada Gambar 2 yang berfungsi membaca nilai $\mathrm{pH}$ yang terdapat dalam larutan. Sensor pada sistem otomatis akan bergerak turun apabila pengukuran $\mathrm{pH}$ dimulai dan akan bergerak naik kembali saat pengukuran $\mathrm{pH}$ selesai. Sinyal-sinyal keluaran dari sensor yang masih berupa sinyal analog di proses telebih dahulu melalui rangkaian pengondisi sinyal agar sesuai dengan sinyal yang dibutuhkan untuk dapat dibaca oleh mikrokontroler ATMega16. Dalam mikrokontroler ATMega16 terjadi perubahan sinyal analog menjadi digital dan pengolahan data sinyal untuk diteruskan ke aktuator $\mathrm{pH}$ kemudian ditampilkan ke display.

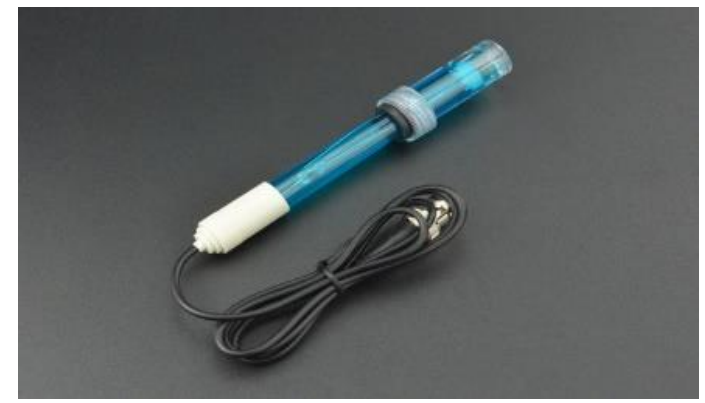

Gambar 2. Probe Sensor pH

Spesifikasi sensor probe $\mathrm{pH}$ :

1. Grade Laboratorium.

2. Range deteksi pH : 0 - 14.

3. Suhu kerja $5-60^{\circ} \mathrm{C}$.

4. Titik netral pad $\mathrm{pH} 7 \pm 0,5$.

5. Waktu respon $<2$ menit.

6. Panjang kabel probe $: 100 \mathrm{~cm}$.

\section{a) Rangkaian Pengondisi Sinyal Sensor $\mathrm{pH}$}

Pada penelitian ini peneliti menggunakan modul/rangkaian pengkondisi sinyal yang di produksi oleh DFROBOT, rangkaian ini satu paket dengan sensor probe $\mathrm{pH}$ seperti yang ditunjukkan pada Gambar 3.

Rangkaian pengondisi sinyal berfungsi untuk menguatkan tegangan keluaran dari sensor menjadi tegangan $0-5 \mathrm{~V}$ agar dapat dibaca oleh ADC mikrokontroler. ADC yang dipergunakan yaitu ADC 10 bit dengan tegangan referensi sebesar $5 \mathrm{~V}$ [11]. Jadi tegangan maksimal yang dapat masuk ke dalam ADC adalah :

$$
\begin{aligned}
\operatorname{Vin}(A D C) & =5 \times(-) \\
& =4,995 \mathrm{~V}
\end{aligned}
$$




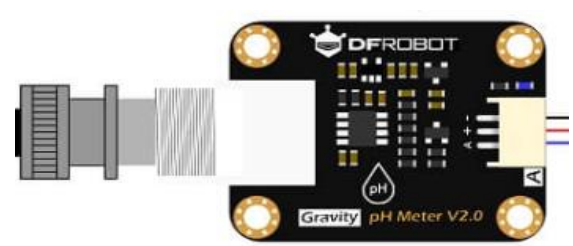

Gambar 3. Modul Pengkondisi Sinyal

Spesifikasi modul pengkondisi sinyal:

1. Tegangan kerja antara $3.3-5.5 \mathrm{v}$.

2. Output tegangan analog: $0-3.0 \mathrm{v}$.

3. Konektor tipe BNC.

4. Tingkat akurasi pengukuran \pm 0.1 .

5. Dimensi board : $42 \mathrm{~mm} \times 32 \mathrm{~mm}$.

b) Perancangan Sistem Otomatis

Perancangan rangkaian sistem otomatis berfungsi mengerakkan sensor $\mathrm{pH}$ naik atau turun secara otomatis seperti yang ditunjukkan pada Gambar 4. Rangkaian sistem ini dapat bergerak naik dan turun meggunakan motor DC.

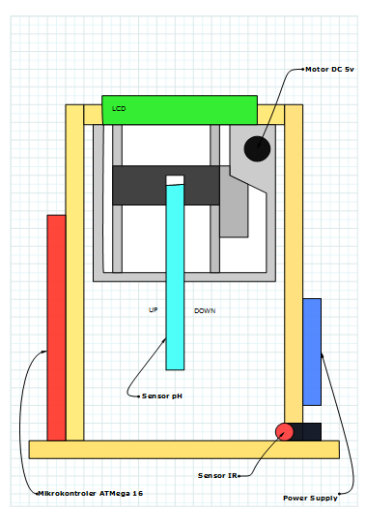

Gambar 4. Rankaian pH Meter Otomatis

Pada alat juga diberi sensor halangan (IR) seperti pada Gambar 5 yang dapat mendeteksi objek ketika larutan dalam wadah diletakkan di bawah sensor $\mathrm{pH}$. Sensor IR akan membaca objek didepannya, maka output sensor akan berlogika 0 sehingga sensor IR akan bekerja sebagai switching yang akan melanjutkan program lain dan apabila sensor IR tidak mendeteksi objek didepanya, maka output sensor akan berlogika 1 .

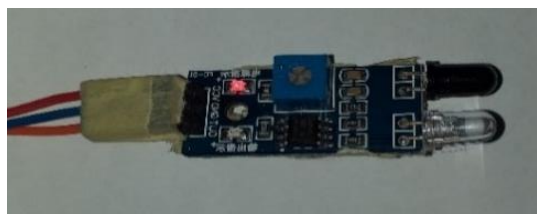

Gambar 5. Sensor IR (sensor halangan) c) Perancangan Rangkaian Power Supply

Perancangan rangkaian power supply ini berfungsi sebagai sumber tegangan atau catu daya bagi $\mathrm{pH}$ meter. Power supply yang digunakan adalah power bank 5000mAH dengan tegangan output 5v. Power bank ini sudah dirasa cukup oleh peneliti, dikarenakan tegangan output, ukuran dan efisiensinya sesuai kebutuhan alat yang dirancang bangun peneliti seperti yang ditunjukkan pada Gambar 6. Power supply ini nantinya akan dipasang/menempel langsung terhadap alat $\mathrm{pH}$ meter.

Spesifikasi power supply yang digunakan sebagai berikut:

1. Kapasitas $=5000 \mathrm{mAh} / 18.5 \mathrm{Wh}$.

2. Input $=\mathrm{DC} 5 \mathrm{~V} / 1500 \mathrm{~mA}$.

3. Output $=\mathrm{DC} 5 \mathrm{~V} / 1500 \mathrm{~mA}$.

4. Dimensi $=87 \mathrm{~mm} \times 41 \mathrm{~mm} \times 25 \mathrm{~mm}$.

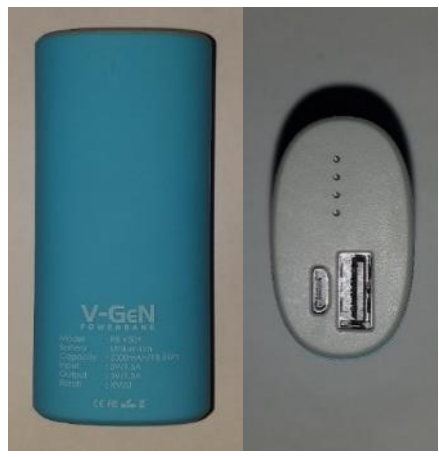

Gambar 6. Power supply

d) Perancangan Rangkaian Mikrokontroler ATMegal6

Perancangan perangkat keras pada sistem $\mathrm{pH}$ meter otomatis ini menggunakan beberapa macam peripheral yang terhubung langsung dengan mikrokontroler sebagai pusat pengolahan data yang berkaitan dengan input atau Output sistem seperti yang ditunjukkan pada Gambar 7.

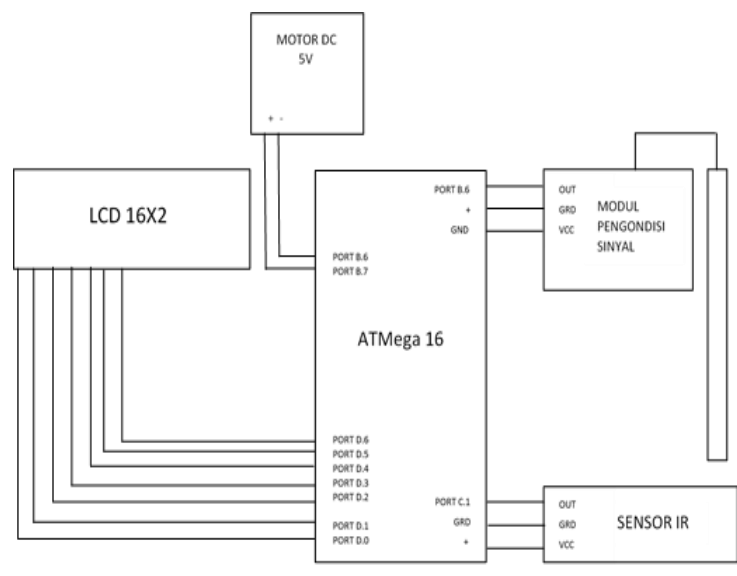

Gambar 7. Rangkaian Mikrokontroler ATMega16 terhadap sensor $\mathrm{pH}$, sensor IR, display LCD dan Motor DC 5v

Mengakses sensor pH dengan keluaran tegangan analog peneliti menggunakanan ATMega16 dengan program CVAVR. Pada sensor $\mathrm{pH}$ juga terdapat sebuah penguat 
sehingga tegangan dapat terbaca oleh mikrokontroler ATMega16. Sensor pH kemudian dipasang dan dihubungkan ke sistem minimum ATMega16.

\section{B. Perancangan Software $\mathrm{pH}$ Meter}

a) Perancangan Pemograman Mikrokontroler ATMegal6

Pemograman mikrokontroler ATMega16 menggunakan software CVAVR Evolution. Tetapi sebelum dilakukan pemograman, terlebih dahulu menentukan rumus persamaan dari kalibrasi sensor dengan larutan standar untuk menghitung nilai $\mathrm{pH}$ yang akan digunakan di software CVAVR Evolution sebagai berikut:

1. Rumus tegangan per bit ADC

2. Rumus tegangan nilai $\mathrm{pH}$

Dimana:

val = read_adc

3. Rumus untuk menetukan persamaan untuk nilai $\mathrm{pH}$

4. Rumus Persamaan nilai $\mathrm{pH}$

Dimana didalam program dinyatakan dengan:

$$
\begin{aligned}
& \mathrm{y}=\text { ph_value } \\
& \mathrm{m}=\text { konstanta } 1 \\
& \mathrm{x}=\text { teg } \\
& \mathrm{b}=\text { konstanta } 2
\end{aligned}
$$

Setelah rumus dibuat, dilanjutkan dengan membuat program untuk ATMega16 yang akan menjalankan alat $\mathrm{pH}$ meter yang dirancang bangun.

\section{HASIL DAN PEMBAHASAN}

\section{A. Pengujian Hardware $\mathrm{pH}$ Meter}

\section{a) Pengujian LCD}

Pengujian subsistem LCD 16x2 dilakukan dengan memprogram untuk menampilkan tulisan atau karakter pada LCD, kemudian mencocokan dengan tampilan karakter pada layar LCD. LCD menampilkan berbagai macam tampilan tulisan tergantung pengukuran nilai $\mathrm{pH}$ dari larutan senyawa tersebut.

\section{b) Pengujian Sensor IR}

Pengujian sistem sensor IR dilakukan dengan mempersiapkan dan menguji kerja sensor IR berfungsi dengan baik atau tidak. Pengujian dilakukan dengan meletakkan objek didepan sensor IR dengan jarak $6 \mathrm{~cm}$ sehingga memungkinkan sensor IR dapat bekerja walaupun bekerja dengan jarak kurang dari $6 \mathrm{~cm}$ seperti yang ditunjukkan seperti pada Gambar 8 .

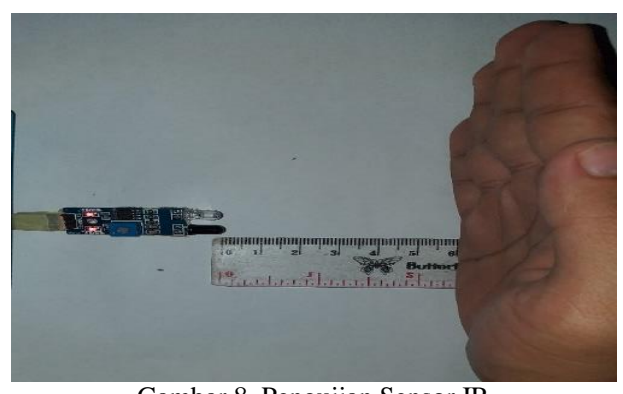

Gambar 8. Pengujian Sensor IR

Apabila sensor membaca objek didepannya, maka output sensor akan berlogika 0 sehingga sensor IR akan bekerja sebagai switching yang akan melanjutkan program lain dan apabila sensor IR tidak mendeteksi objek didepanya, maka output sensor akan berlogika 1. Indikator dalam pengujian sensor IR ini akan ditunjukkan dengan nyala kedua lampu pada sensor dan perubahan tampilan display $L C D$ yang menampilkan tulisan berupa "Analyzing" jika sensor IR bekerja dengan baik seperti pada Gambar 9 .

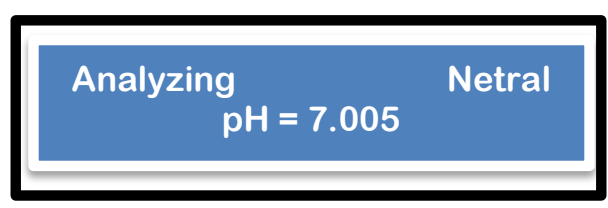

Gambar 9. Contoh Tampilan $L C D$

\section{c) Pengujian Motor}

Pengujian subsistem motor dengan mempersiapkan dan menguji kerja motor berfungsi dengan baik atau tidak. Pengujian dilakukan dengan memberi masukan logika 1 dan 0 pada program CVAVR terhadap motor. Apabila positif (+) motor diberikan masukan 1 dan negatif (-) motor diberikan masukan 0, maka probe $\mathrm{pH}$ akan bergerak turun. Sebaliknya probe $\mathrm{pH}$ akan bergerak naik, apabila positif (+) motor diberikan masukan 0 dan negatif (-) motor diberikan masukan 1 .

\section{d) Pengujian Power supply}

Pengujian subsistem power supply dilakukan dengan dengan cara menyambungkan USB mikrokontroler dengan power bank seperti yang ditunjukkan pada Gambar 10 . Indikator lampu pada USB akan menyala apabila power bank berfungsi. Pengujian lain juga dilakukan dengan mengukur tegangan masukan pada pin ground dan vec mirkrokontroler dan pada pengkondisi sinyal. 


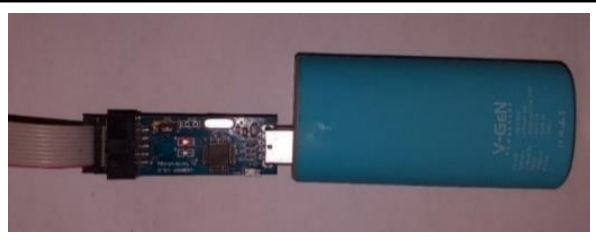

Gambar 10. Pengujian Power Supply

\section{e) Pengujian Sensor $\mathrm{pH}$}

Pengujian sensor $\mathrm{pH}$ bertujuan untuk mengetahui kerja dari sensor untuk pembacaan tingkat keasaman pada cairan. Pengujian dilakukan dengan menghubungkan sensor $\mathrm{pH}$ ke PORT A.0 mikrokontroler dan melakukan pengujian sampel sebanyak lebih dari 30 kali. Outputnya berupa LCD untuk menampilkan display tingkat keasaman pH. Jika hasil yang terbaca oleh sensor masih berbeda jauh dan tidak stabil selama pengujian sebanyak lebih dari 30 kali maka harus dilakukan kalibrasi ulang, jika kedua hasil sudah menunjukkan hasil yang sama ataupun medekati maka sensor sudah bekerja dengan baik.

\section{B. Pengukuran Software $\mathrm{pH}$ Meter}

Pengujian software $\mathrm{pH}$ dilakukan untuk menunjukkan apakah program yang dibuat menggunakan CVAVR dapat bekerja sesuai dengan yang diinginkan. Sebelum program diimplementasikan kepada $\mathrm{pH}$ meter, terlebih dahulu program di compile agar supaya diketahui ada tidaknya program yang mengalami error. Setelah prorgam yang dibuat tidak terdapat error, maka program yang dibuat dapat langsung diimplementasikan terhadap alat $\mathrm{pH}$ meter yang dirancang bangun.

\section{Pengujian ADC dan Kalibrasi}

Pengujian adc dan kalibrasi menggunakan buffer $\mathrm{pH} 4.00$ dan buffer pH 7.00 seperti yang ditunjjukan Gambar 11. Hasil pembacaan adc pada larutan buffer $\mathrm{pH} 4.00$ dan 7.00 digunakan sebagai acuan untuk menentukan rumus dan kalibrasi alat. Untuk pengujian adc dan kalibrasi dilakukan sebanyak tujuh kali setiap buffer.

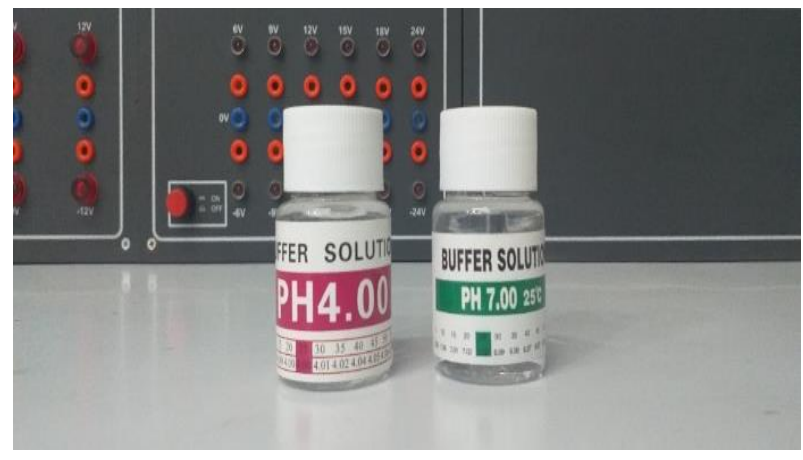

Gambar 11. Larutan Standar Buffer pH 4.00 dan 7.00

\section{Pengujian Akurasi Alat}

Pengujian akurasi alat dilakukan dengan cara membandingkan hasil pengukuran $\mathrm{pH}$ meter rancang bangun peneliti dengan menggunakan $\mathrm{pH}$ meter yang telah terstandar dari laboratorium PT. PKT Bontang. Hasil pengukuran $\mathrm{pH}$ dari dari laboratorium PT. PKT Bontang digunakan sebagai rujukan akurasi alat. Sampel yang diuji merupakan larutan senyawa kimia seperti yang ditunjukkan pada Gambar 12.

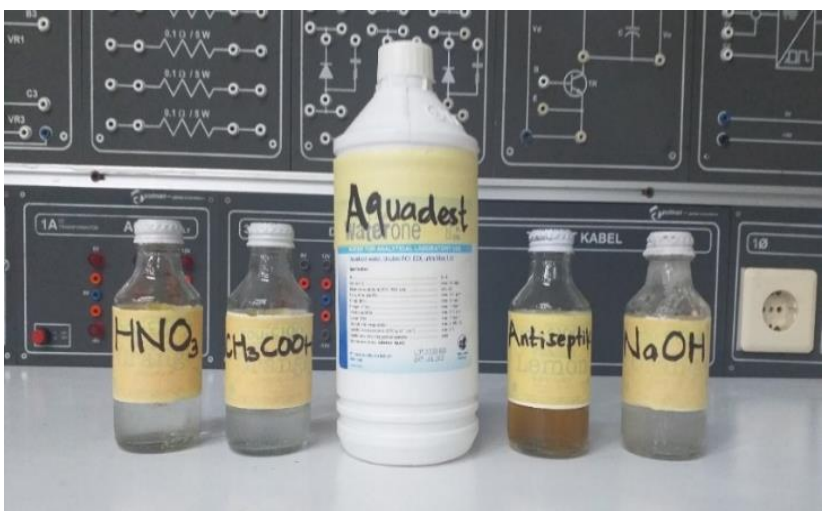

Gambar 12. Sampel Pengujian

\section{E. Pengujian Kerja Sistem Keseluruhan}

Pengujian kerja sistem dilakukan untuk menunjukkan apakah keseluruhan sistem telah dapat bekerja sesuai dengan yang diinginkan. Pengujian ini terdiri atas pengujian terhadap fungsi-fungsi dari sistem dan juga meliputi pengecekan semua rangkaian dari alat $\mathrm{pH}$ meter yang dirancang bangun.

\section{F. Hasil Pengukuran Tegangan Referensi}

Dari hasil percobaan yang dilakukan peneliti, didapatkan hasil berupa tegangan referensi yang diukur menggunakan Multimeter digital yang ditunjukkan Tabel 1 dibawah ini.

TABel I. Pengukuran Tergangan Referensi Dengan Multimeter Digital

\begin{tabular}{|c|c|}
\hline No. & Tegangan \\
\hline 1. & 4.70 \\
\hline 2. & 4.71 \\
\hline 3. & 4.72 \\
\hline 4. & 4.72 \\
\hline 5. & 4.72 \\
\hline 6. & 4.65 \\
\hline 7. & 4.64 \\
\hline 8. & 4.59 \\
\hline 9. & 4.70 \\
\hline 10. & 4.75 \\
\hline Rata-rata & $\mathbf{4 . 6 9}$ \\
\hline
\end{tabular}

Hasil rata-rata pengukuran tegangan digunakan dalam rumus untuk menentukan tegangan per bit dari $A D C$ yang dinyatakan 
Risal Arief, Hardianto, Arief Muliawan, Rancang Bangun pH Meter Otomatis Menggunakan ATMegal6 Dalam Upaya Peningkatan Akurasi Pembacaan pH Larutan Senyawa Kimia.

dengan "teg" dalam program yang dibuat dengan rumus sebagai berikut:

\section{G. Hasil Kalibrasi Alat}

Data hasil kalibrasi alat seperti yang ditunjukkan pada Tabel 2 merupakan hasil pengukuran larutan Buffer 4.00 dan 7.00 yang merupakan larutan standar untuk kalibrasi alat yang bersifat asam.

TABEL II. PENGUKuran TERgangan REFERENSI DENGAN MULTIMETER DiGITAL

\begin{tabular}{|c|c|c|c|c|}
\hline \multirow{2}{*}{ No. } & \multicolumn{2}{|c|}{ Buffer $\mathrm{pH} 4.00$} & \multicolumn{2}{c|}{ Buffer $\mathrm{pH} 7.00$} \\
\cline { 2 - 5 } & ADC & Tegangan & ADC & Tegangan \\
\hline 1. & 427 & 1.958 & 321 & 1.472 \\
\hline 2. & 422 & 1.935 & 329 & 1.508 \\
\hline 3. & 422 & 1.935 & 329 & 1.508 \\
\hline 4. & 422 & 1.935 & 319 & 1.462 \\
\hline 5. & 432 & 1.981 & 319 & 1.462 \\
\hline 6. & 438 & 2.008 & 319 & 1.462 \\
\hline 7. & 427 & 1.958 & 323 & 1.481 \\
\hline $\begin{array}{c}\text { Rata- } \\
\text { rata }\end{array}$ & $\mathbf{4 2 7 . 1 4 2}$ & $\mathbf{1 . 9 5 8}$ & $\mathbf{3 2 2 . 7 1 4}$ & $\mathbf{1 . 4 8 0}$ \\
\hline
\end{tabular}

Dari rata-rata hasil kalibrasi didapatkan grafik linier seperti Gambar 13 dibawah ini:

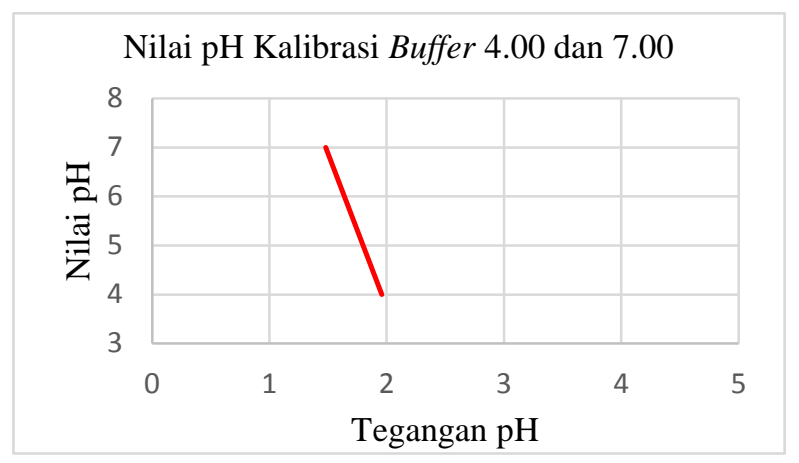

Gambar 13. Grafik Linear Kalibrasi Nilai pH Larutan Standar

Sehingga hasil rata-rata kalibrasi dimasukkan dalam rumus pada program dimana rumus dinyatakan sebagai berikut:

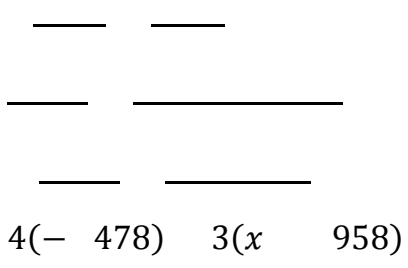

\section{H. Hasil Pengujian Sensor pH}

Dalam penelitian juga dilakukan pengukuran sampel Aquadest sebanyak $>30$ kali sebagai acuan alat yang dirancang bangun peneliti dapat mengukur $\mathrm{pH}$ dengan baik dan dapat digunakan berulang kali. Data hasil pengukuran $\mathrm{pH}$ Aquadest ditunjukkan pada Tabel 3.

TABel 3. PEngukuran Nilai PH SEBANYAK > 30 Kali.

\begin{tabular}{|c|c|}
\hline \multirow{2}{*}{ No. } & Nilai pH \\
\hline & Sampel : Aquadest \\
\hline 1 & 5.959 \\
\hline 2 & 5.987 \\
\hline 3 & 5.987 \\
\hline 4 & 6.009 \\
\hline 5 & 6.074 \\
\hline 6 & 6.074 \\
\hline 7 & 5.959 \\
\hline 8 & 5.987 \\
\hline 9 & 6.045 \\
\hline 10 & 5.987 \\
\hline 11 & 6.074 \\
\hline 12 & 6.074 \\
\hline 13 & 6.074 \\
\hline 14 & 5.959 \\
\hline 15 & 5.959 \\
\hline 16 & 6.074 \\
\hline 17 & 5.959 \\
\hline 18 & 5.987 \\
\hline 19 & 6.045 \\
\hline 20 & 5.987 \\
\hline 21 & 6.074 \\
\hline 22 & 6.074 \\
\hline 23 & 5.959 \\
\hline 24 & 6.074 \\
\hline 25 & 6.045 \\
\hline 26 & 5.987 \\
\hline 27 & 6.074 \\
\hline 28 & 6.045 \\
\hline 29 & 6.074 \\
\hline 30 & 6.074 \\
\hline 31 & 6.045 \\
\hline 32 & 6.074 \\
\hline
\end{tabular}

\section{Hasil Pengukuran Sampel}

Penelitian alat dilakukan dengan cara menguji kerja alat dalam melakukan analisa $\mathrm{pH}$ larutan kimia berupa $\mathrm{HNO}_{3}$ 
(Asam Nitrat), $\mathrm{CH}_{3} \mathrm{COOH}$ (Asam Cuka), Aquadest, Antiseptik, dan $\mathrm{NaOH}$. Hasil analisa berupa nilai $\mathrm{pH}$ dan standar deviasi dari hasil analisa seperti yang ditunjukkan pada Tabel 4.

TABEL 4. NILAI RATA-RATA PH DAN STANDAR DEVIASINYA.

\begin{tabular}{|c|c|c|c|c|c|c|}
\hline No. & Sampel & \multicolumn{3}{|c|}{ Nilai $\mathrm{pH}$} & $\begin{array}{c}\text { Rata- } \\
\text { rata }\end{array}$ & $\begin{array}{c}\text { Standar } \\
\text { Deviasi }\end{array}$ \\
\hline 1. & $\begin{array}{c}\mathrm{HNO}_{3} \\
\text { (Asam Nitrat) }\end{array}$ & -0.813 & -0.813 & -0.835 & -0.820 & 0.013 \\
\hline 2. & $\begin{array}{c}\mathrm{CH}_{3} \mathrm{COOH} \\
\text { (Asam Cuka) }\end{array}$ & 2.082 & 2.134 & 2.082 & 2.099 & 0.030 \\
\hline 3. & Aquadest & 6.074 & 6.045 & 6.074 & 6.064 & 0.017 \\
\hline 4. & Antiseptik & 8.983 & 9.011 & 9.011 & 9.002 & 0.016 \\
\hline 5. & $\begin{array}{c}\text { NaOH } \\
\text { (Natrium } \\
\text { Hidroksida) }\end{array}$ & 10.817 & 10.817 & 10.767 & 10.800 & 0.029 \\
\hline
\end{tabular}

Perhitungan:

Standar Deviasi :

$\begin{array}{llll} & & \frac{n \sum n-\left(\sum n_{i}\right)^{2}}{\mathrm{n}(\mathrm{n} 1)}(10) \\ \mathrm{HNO}_{3} & : & \frac{3(2019)-(-461)^{2}}{3(31)} & \\ \mathrm{CH}_{3} \mathrm{COOH} & : & \frac{3(13223)-(698)^{2}}{3(31)} & \\ \text { Aquadest } & : & \frac{3(110329)-(1893)^{2}}{3(31)} & 0.017 \\ \text { Antiseptik } & : & \frac{3(24391)-(27005)}{3(31)} & \\ \mathrm{NaOH} & : & \frac{3(3493)-(32041)}{3(31)}\end{array}$

\section{J. Hasil Perbandingan Dengan Alat Terstandar}

Untuk mengetahui $\mathrm{pH}$ meter peneliti dapat mengukur $\mathrm{pH}$ dengan akurat dilakukan perbandingan hasil dengan $\mathrm{pH}$ Meter terstandar dari PT. PKT. Hasil perbandingan nilai $\mathrm{pH}$ ditunjjukan pada Tabel 5.

Tabel 5. Perbandingan Hasil Pengukuran Nilai PH.

\begin{tabular}{|c|c|c|c|}
\hline Sampel & $\begin{array}{c}\text { pH Meter } \\
\text { PT. PKT }\end{array}$ & $\begin{array}{c}\text { pH Meter } \\
\text { Rancang } \\
\text { Banngun }\end{array}$ & Selisih \\
\hline $\begin{array}{c}\mathrm{HNO}_{3} \text { (Asam } \\
\text { Nitrat) }\end{array}$ & -0.78 & -0.82 & 0.04 \\
\hline $\begin{array}{c}\mathrm{CH}_{3} \mathrm{COOH} \\
\text { (Asam Cuka) }\end{array}$ & 2.05 & 2.09 & 0.04 \\
\hline Aquadest & 5.97 & 6.06 & 0.09 \\
\hline Antiseptik & 8.93 & 9.00 & 0.07 \\
\hline $\begin{array}{c}\text { NaOH } \\
\text { Natrium } \\
\text { Hidroksida) }\end{array}$ & 10.73 & 10.80 & 0.07 \\
\hline
\end{tabular}

Dari penelitian yang telah dilakukan oleh peneliti didapati hasil secara keseluruhan berdasarkan parameter uji yang yang dilakukan peneliti sebagai rujukan alat yang dirancang bangun oleh peneliti bekerja dengan baik atau tidak. Hasil pengamatan peneliti terhadap alat ditunjukkan pada Tabel 6 .

TABEL 6. PARAMETER UJI.

\begin{tabular}{|c|c|c|}
\hline No. & Parameter Uji & Pengamatan \\
\hline 1. & $\begin{array}{l}\text { Tegangan } \\
\text { Referensi }\end{array}$ & $4.69 \mathrm{v}$ \\
\hline 1. & $\begin{array}{l}\text { Akurasi } \\
\text { Pembacaan }\end{array}$ & $<0.1$ \\
\hline 3. & Response Time & \pm 2 menit \\
\hline 2. & Sistem Otomasi & $\begin{array}{l}\text { Sistem Otomasi bekerja } \\
\text { dengan baik }\end{array}$ \\
\hline 3. & $\begin{array}{l}\text { Eksekusi } \\
\text { Program }\end{array}$ & Eksekusi program sesuai \\
\hline 4. & $\begin{array}{l}\text { Pengkondisian } \\
\text { Sensor Probe } \\
\mathrm{pH}\end{array}$ & $\begin{array}{l}\text { Sensor probe } \mathrm{pH} \text { harus selalu } \\
\text { dibilas dan dilap saat menguji } \\
\text { sampel berikutnya. }\end{array}$ \\
\hline 5. & $\begin{array}{l}\text { Respon Sensor } \\
\text { IR Halangan }\end{array}$ & $\begin{array}{l}\text { Posisi tangan kanan saat } \\
\text { meletakkan wadah sampel } \\
\text { harus melewati sensor ir agar } \\
\text { sensor dapat merespon. }\end{array}$ \\
\hline 6. & $\begin{array}{ll}\text { Kerja } & \text { Motor } \\
\text { DC 5v } & \end{array}$ & $\begin{array}{l}\text { Motor DC } 5 \mathrm{v} \text { bekerja dengan } \\
\text { baik dalam menjalakan sistem } \\
\text { otomasi dari } \mathrm{pH} \text { meter }\end{array}$ \\
\hline 7. & $\begin{array}{l}\text { Kerja Power } \\
\text { Supply }\end{array}$ & $\begin{array}{l}\text { Power Supply otomatis mati } \\
\text { setelah } 30 \text { detik saat } \mathrm{pH} \text { meter } \\
\text { dimatikan. }\end{array}$ \\
\hline 8. & Kalibrasi alat & $\begin{array}{l}\text { Kalibrasi } \\
\text { menggunakan larutan buffer } \\
\text { pH 4.00 dan pH 7.00. }\end{array}$ \\
\hline 9. & $\begin{array}{l}\text { Penyimpanan } \\
\text { Alat }\end{array}$ & $\begin{array}{l}\text { Sensor probe } \mathrm{pH} \text { direndam } \\
\text { dalam Aquadest. }\end{array}$ \\
\hline
\end{tabular}

\section{PENUTUP}

Dari penelitian yang dilakukan dapat disimpulkan bahwa $\mathrm{pH}$ meter yang dirancang bangun oleh peneliti dapat memenuhi tujuan dari peneliti dimana akurasi pembacaan nilai $\mathrm{pH}$ lebih baik dari pada pengukuran dengan indikator konvensional serta otomasi dari $\mathrm{pH}$ meter dapat meminimalisir bahaya akibat berinteraksi langsung dengan larutan senyawa kimia. pH meter dapat berfungsi dengan baik selama melakukan pengukuran pH Aquadest sebanyak > 30 kali uji. Didapatkan pula hasil pembacaan nilai $\mathrm{pH}$ mendekati akurasi pH meter laboratorium PT. PKT yang telah terstandarisasi menggunakan sampel yang sama. Hasil akurasi pembacaan nilai $\mathrm{pH}<0.1$, dimana hasil ini dapat menunjukkan bahwa $\mathrm{pH}$ ini layak digunakan sebagai instrumen ukur atau sebagai bahan ajar di perguruan tinggi dan sekolah-sekolah yang masih menggunakan indikator konvensional. 
Saran untuk pengembang yaitu dibutuhkan peningkatan lebih lanjut terhadap alat dari segi penyimpanan data pengujian dan diharapakan alat dapat bekerja otomatis secara keseluruhan agar dapat memudahkan kerja pengoperasi alat

\section{DAFTAR PUSTAKA}

[1] S. Haryati, "Pengembangan Lembar Kerja Siswa Untuk Pokok Bahasan Asam Basa Berbasis Bahan Alam Menggunakan Buah Pucuk Merah (Syzygium campanulatum korth)," J. Pendidik. Kim. Univ. Riau, vol. 1, no. 1, pp. 14-23, 2016.

[2] C. Indira, "Pembuatan Indikator Asam Basa Karamunting," J. Kaunia, vol. 11 , no. 1 , pp. 1-10, 2015.

[3] W. Muhammad Hizbul, E. Yuliyanto, and M. Retnoyuanni, "Pemanfaatan Bunga Tapak Dara Sebagai Alternatif Pembuatan Indikator pH Asam-Basa," Pelita-Jurnal Penelit. Mhs. UNY, no. 1, 2009.

[4] I. Tahir, "Arti Penting Kalibrasi pada Proses Pengukuran Analitik: Aplikasi pada Penggunaan pHmeter dan Spektrofotometer UV-VIS," Yogyakarta Univ. Gajah Mada, 2008.
[5] A. Setyaningrum and A. Asngad, "Pemanfaatan Daun Adam Hawa Sebagai Indikator Asam Basa Alternatif Dengan Variasi Suhu Pengeringan dan Jenis Pelarut." Universitas Muhammadiyah Surakarta, 2017.

[6] I. W. Redhana, "Identifikasi Bahan Kimia Berbahaya yang Digunakan dalam Praktikum Kimia SMA," in Prosiding Seminar Nasional MIPA, 2013.

[7] A. S. Alam and H. Matalata, "Perancangan Alat Pengolahan Air Minum Otomatis Pada Proses Netralisasi pH Dan Aerasi," J. Electr. Power Control Autom., vol. 1, no. 2, pp. 33-38, Dec. 2018.

[8] D. I. S. Saputra, "Rancang Bangun Alat Penghitung Jumlah Pengunjung di Toko Adhelina Berbasis Mikrokontroler Atmega 16," J. Sisfokom (Sistem Inf. dan Komputer), vol. 4, no. 1, pp. 16-21, 2015.

[9] T. Malinowski, T. Mikolajczyk, and A. Olaru, "Control of articulated manipulator model using ATMEGA16," in Applied Mechanics and Materials, 2014, vol. 555, pp. 147-154.

[10] M. A. H. Koli, "Rancang Bangun Robot Bawah Air Mini ROV (Remotely Operated Vehicles) Berbasis Mikrokontroler ATMega16," J. Tek. Elektro Univ. Tanjungpura, vol. 2, no. 1.

[11] M. Shidiq and P. M. Rahardjo, "Pengukur Suhu dan pH Air tambak terintegrasi dengan data logger," J. EECCIS, vol. 2, no. 1, pp. 22-25, 2012. 